\title{
A Study on Heavy Metal Pollutants in Water and Tilapia at Lake Temsah
}

\section{Eissa I.A. M' , Derwa, H. I. ', Mona Abdelwahab', Wafeek, M. ${ }^{r}$, and Shimaa Fakhry ${ }^{r}$}

${ }^{1}$ Dept. of Fish Diseases and Management, Fac. of Vet. Medicine, Suez Canal Univ . ${ }^{2}$ Animal Health Research Institute, Ismailia branch.

${ }^{3}$ Central lab. for Aquaculture Research, El-Abbassa.

\begin{abstract}
A total of 120 Oreochromis niloticus were collected randomly and seasonally. Fish were examined freshly from western lagoon (Berket El-Siadin) which is branch from Lake Temsah in Ismailia governorate the result revealed that post mortem lesions in liver was in the form of pale and enlargement in some cases, while in other cases showed variable degrees of congestion and hemorrhage spots. Spleen was dark in color and enlarged, kidneys appeared congested and the gall bladder was full and distended. The periodic difference of heavy metals concentration based on the data of water samples gathered from the same lagoon showed the following manner as: summer $>$ autumn $>$ winter. The results revealed the presence of metals in the following order: $\mathrm{Fe}>\mathrm{Cu}>\mathrm{Pb}>\mathrm{Zn}>\mathrm{Cd}$. The concentration of heavy metals in fish liver, gills and musculature were always higher than of the water, indicating the bioaccumulation. The highest concentration of heavy metals in water and fish tissue was associated with the lowest RBCs count, $\mathrm{Hb}$, PCV, leukocytosis, hypoproteinemia and elevation in serum AST and ALT levels than normal. So, there is accumulating evidence that some heavy metals are immunosuppressive and fish may be more exposed to disease.
\end{abstract}

Key words: Oreochromis niloticus, Berket El-Siadin, Lake Temsah, Heavy metals, Blood parameters.

\section{Introduction}

In Ismailia, as a coastal city where are people basically depend on fish as a main source of animal protein; most caught from Suez Canal and lake Temsah. In the same time, agriculture is considered one of the driving forces of Egypt's economy, thus intensive agriculture systems

have been employed in order that agriculture can cope with the massive population, which led to the extensive use of pesticides resulting in various problems 
(Abdel Fattah, 1992 and Senthilkumar et al, 2001).

Contamination of aquatic ecosystem by industrial and agricultural pollutants may affect the health of fish, either directly by uptake from the water, or indirectly through their diet of vegetation, invertebrates or smaller fish. While the obvious signs of group pollution, dead fish, have long been recognized, there is increasing evidence that low-level pollution may decrease the fecundity of fish population, leading to long term decline in fish numbers (Mona Zaki et al, 2015).

Heavy metal contamination may have devastating effects on the ecological balance of the aquatic environment and a diversity of aquatic animals (Farombi, et al, 2007). Various studies on different fish species have confirmed that heavy metals may cause undesirable changes in the physiological activities and biochemical parameters both in tissues and in blood (Basa and Rani, 2003). Fish develop a protective defense mechanism against the harmful effects of xenobiotic like essential and inessential heavy metals that produce degenerative changes in the fish physiology (Abou EL-Naga et al, 2005).

The present study aimed to investigate the water pollutants in Lake Temsah, focusing on heavy metal analysis of water, fish organs and tissues and it's reflect on blood parameters.

\section{Materials and Methods \\ Fish:}

In the present investigation, a total of 120 Oreochromis niloticus of total length $(23 \pm 5 \mathrm{~cm})$ and average body weight $(257 \pm 10 \mathrm{~g}) \quad$ were collected randomly and seasonally. They were examined freshly from western lagoon which is a branch from Lake Temsah in Ismailia governorate.

\section{Water sampling:}

Atotal of 30 water samples were collected in pre-cleaned and acidified glass bottles during the period from summer to winter and subjected for heavy metals $(\mathrm{Zn}, \mathrm{Cu}$, $\mathrm{Pb}, \mathrm{Cd}$ and $\mathrm{Fe}$ ) analysis.

\section{Clinical picture}

All fish were clinically examined for detecting any abnormalities. The postmortem examination was performed on all freshly dead and moribund fish according to Conroy and Herman (1981).

\section{Heavy metals analysis}

\section{1-In water samples:}

Water was collected in pre-cleaned and acidified glass bottles. The bottles were immediately brought to the laboratory and acidified with concentrated $\mathrm{HNO} 3$ acid to $\mathrm{pH}$ less than 2.0. Water samples were then analyzed for the presence of heavy metals $(\mathrm{Zn}, \mathrm{Cu}, \mathrm{Pb}, \mathrm{Cd}$ and $\mathrm{Fe}$ ) according to the standard method for analysis of water and waste water $\boldsymbol{A P H A}$ (2005). The obtained clear filtrate was kept in clean dry bottles of $100 \mathrm{ml}$ capacity and samples were kept at $4{ }^{\circ} \mathrm{C}$ till the time of analysis. 
2-In fish tissue:

Sample Preparation for heavy metals analysis:

Each fish specimen was properly cleaned by rinsing with distilled water to remove debris and other external adherent then frozen at -20 ${ }^{\circ} \mathrm{C}$ prior to analysis. For analysis the fish specimens were defrosted for 2 hour then were dissected using stainless steel scalpels and Teflon forceps for their liver, gills and musculature. A part of the musculature without skin and the liver and gills were removed and transferred in polypropylene vials. All digested samples were filtered and analyzed for zinc, lead, cadmium, cupper and iron using Atomic Absorption Spectrophotom(Massanyi et al, 2003). eter (Model Thermo Electron Corporation, S. Series AA Spectrometer, UK,). The analytical procedure was checked using reference material

\section{Haematological analysis}

Blood was collected by heart puncture of the fish using heparinised syringe in vials containing EDTA as an anticoagulant, which was used to estimate $\mathrm{RBC}, \mathrm{Hb}, \mathrm{PCV}, \mathrm{MCV}$, $\mathrm{MCH}, \mathrm{MCHC}$, Total count of WBC and differential Leukocytic count by Shah and Altindag (2004a). The collected blood samples were centrifuged to get sera for the following analyses of Serum total protein by King and Wootton (1959) and AST and ALT by Reitmans and Frankel (1957).

\section{Statistical analysis}

The data was processed using the one-way analysis of variance (ANOVA). Duncan's test (Duncan, 1955) was further used to evaluate the mean differences at $\mathrm{P}<0.05$ significant levels.

\section{Results}

\section{Clinical picture}

The external examination performed on Nile tilapia $O$. niloticus that some fish revealed no pathognomic clinical abnormalities, they showed slimy body with pale skin while other showed hemorrhagic areas on abdomen, base of dorsal fins and pectoral fins. P.M. examination of freshly dead fish revealed enlarged pale liver, enlarged full distended gall bladder and enlarged congested spleen. Otherwise, in some cases, showed enlargement and variable degrees of congestion in liver, congested gills and congestion of the kidneys. 
Heavy metals mean concentration in the water

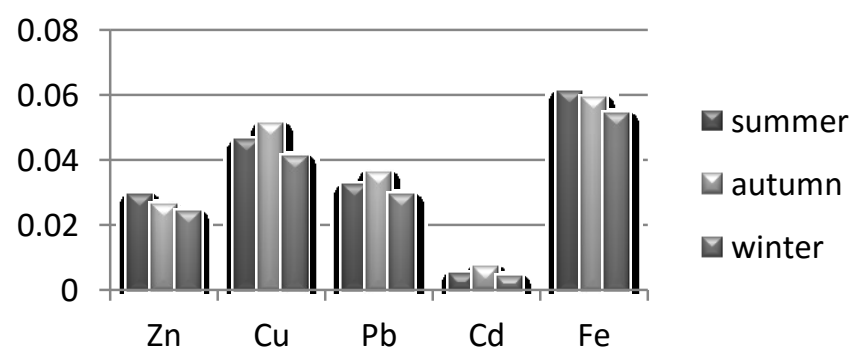

Figure 1: showing different mean concentration of heavy metals in water.

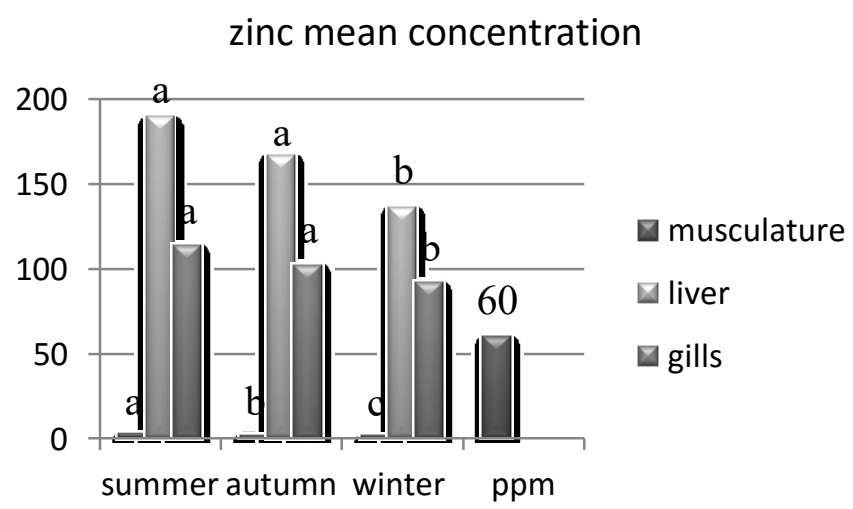

Figure 2: showing the mean concentration of $\mathrm{Zn}$ in O.niloticus.

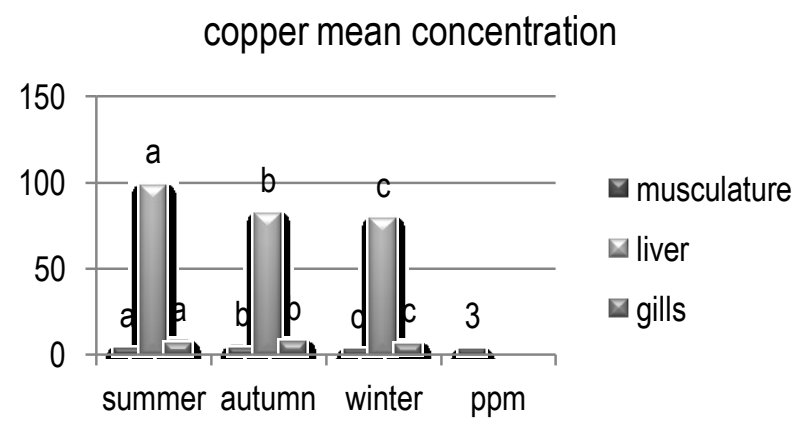

Figure 3: showing the mean concentration of $\mathrm{Cu}$ in $O$. niloticus. 
lead mean concentration

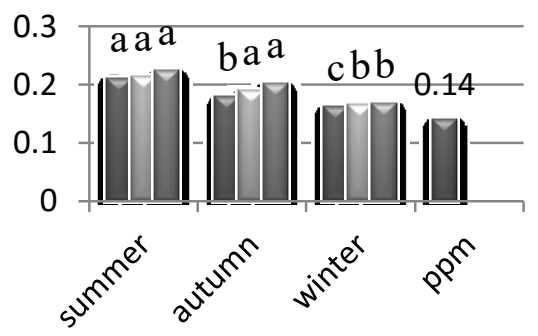

D musculature

$\square$ liver

$\square$ gills

Figure 4: showing the mean concentration of $\mathrm{Pb}$ in $O$. niloticus.

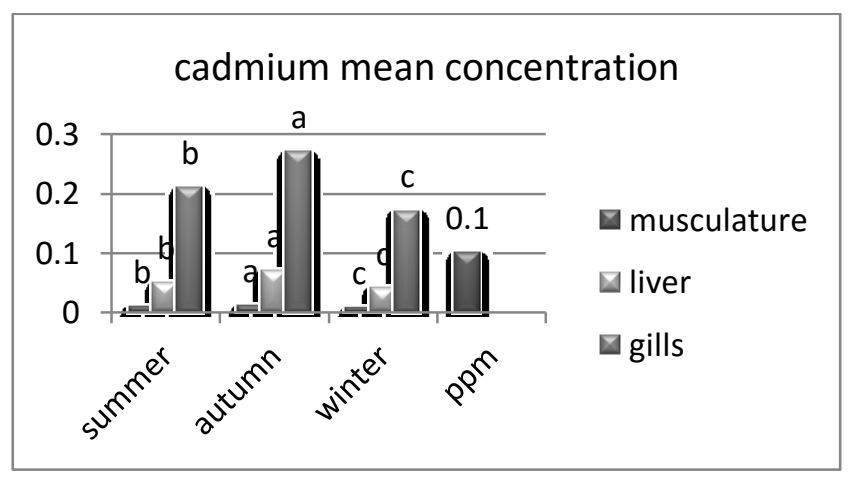

Figure 5: showing the mean concentration of $\mathrm{Cd}$ in O.niloticus .

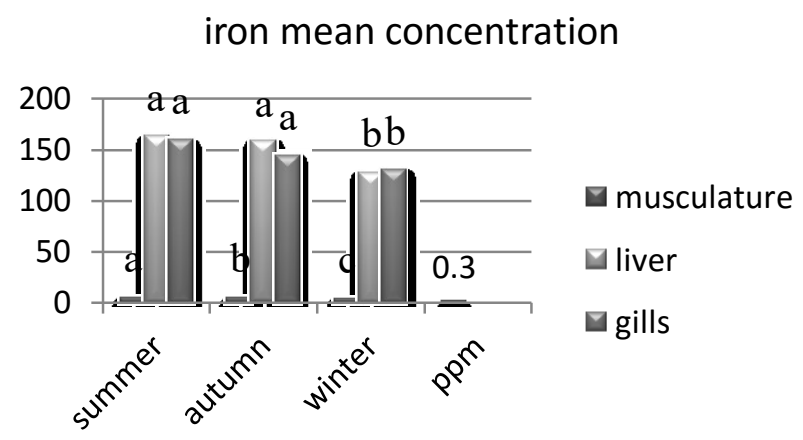

Figure 6: showing the mean concentration of the Fe in $O$, niloticus. 


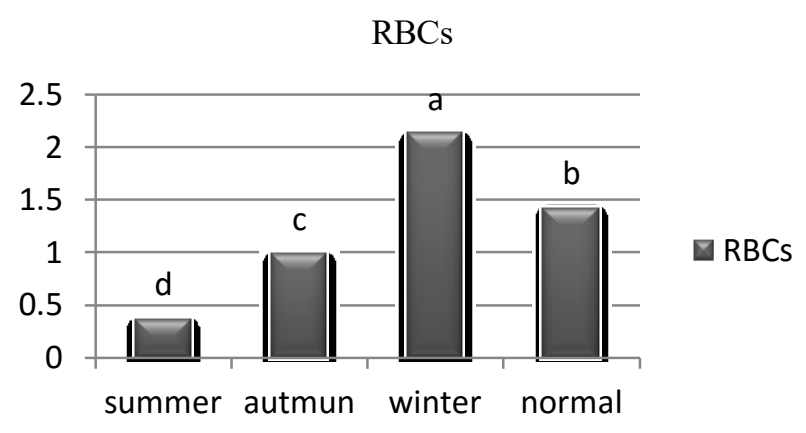

Figure 7: showing the mean concentration of the RBCs of $O$. niloticus.

$\mathrm{Hb}$

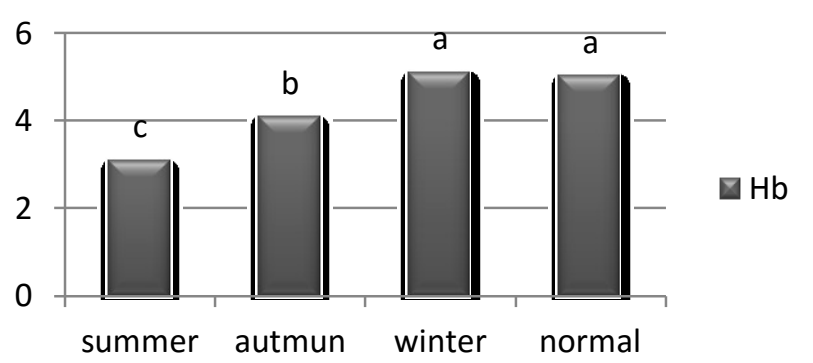

Figure 8: showing the mean concentration of the $\mathrm{Hb}$ in $O$. niloticus.

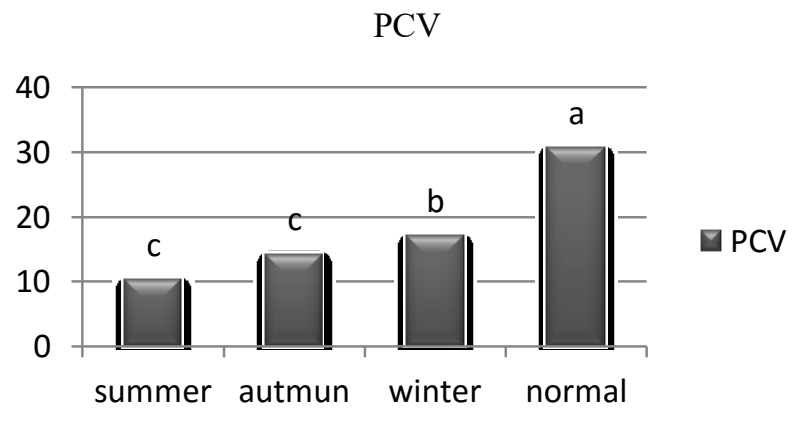

Figure 9: showing the mean concentration of the PCV of $O$. niloticus. 


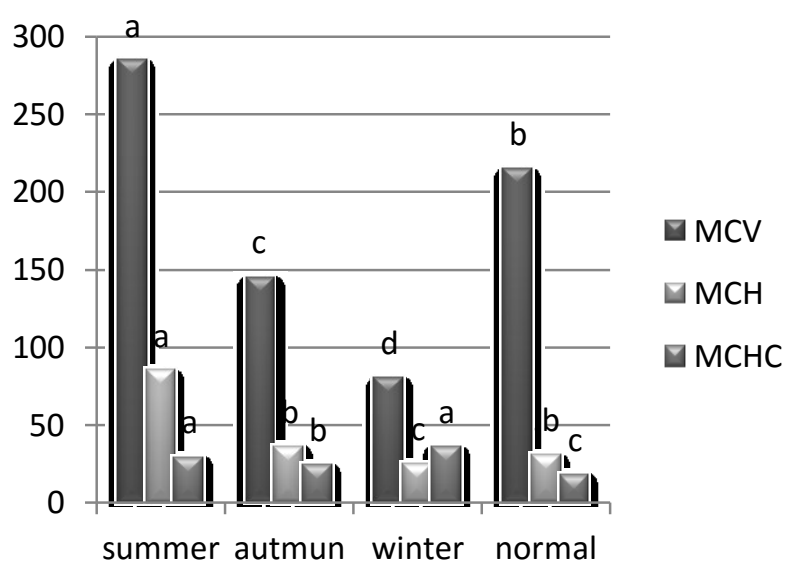

Figure 10: showing the mean concentration of the $\mathrm{MCV}, \mathrm{MCH}$, and $\mathrm{MCHC}$ of $O$. niloticus.

Column carry different superscripts letter are statically significantly different at $(\mathrm{P} \leq 0.05)$.

WBCs

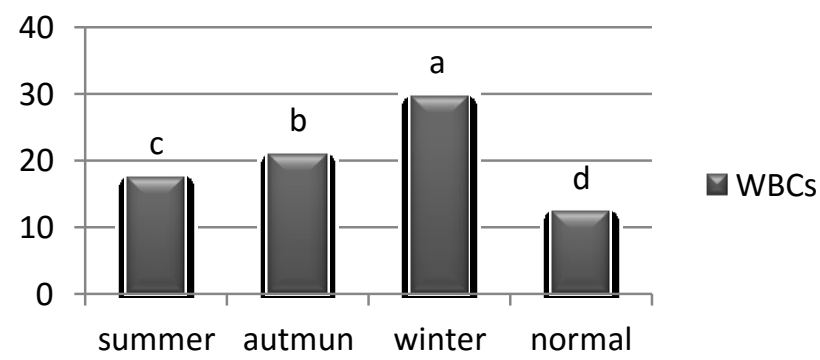

Figure 11: showing the mean concentration of the WBCs of $O$. niloticus.

Differential Leukocytic count

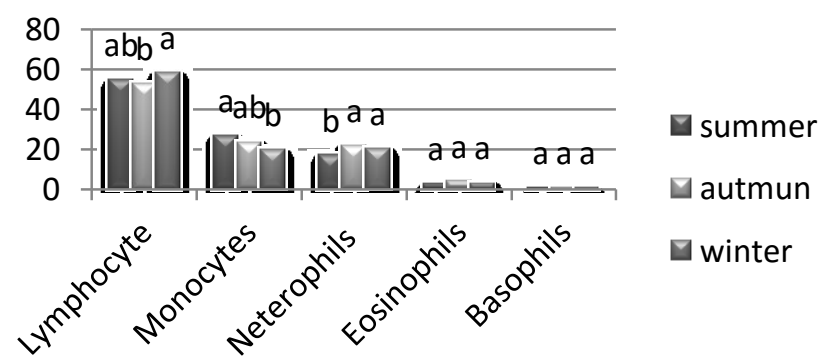

Figure 12: showing the mean concentration of the differential Leukocytic count of O.niloticus. 


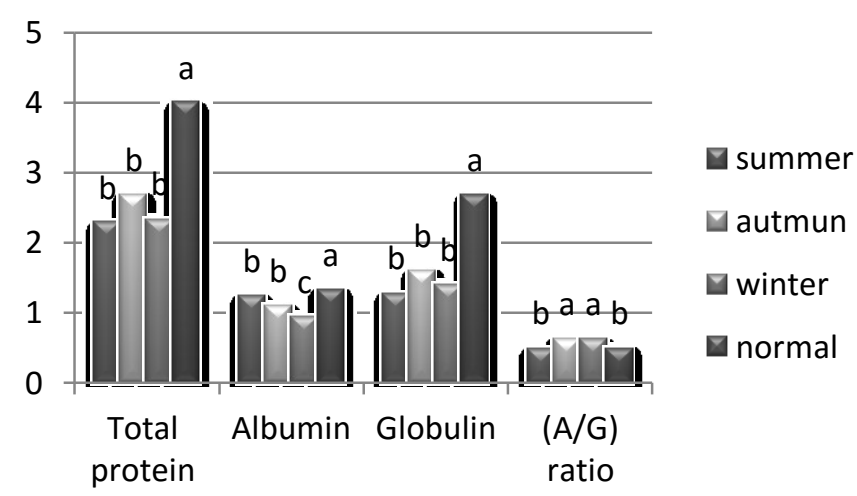

Figure 13: showing the mean concentration of the total protein, albumin, and globulin of serum of $O$. niloticus.

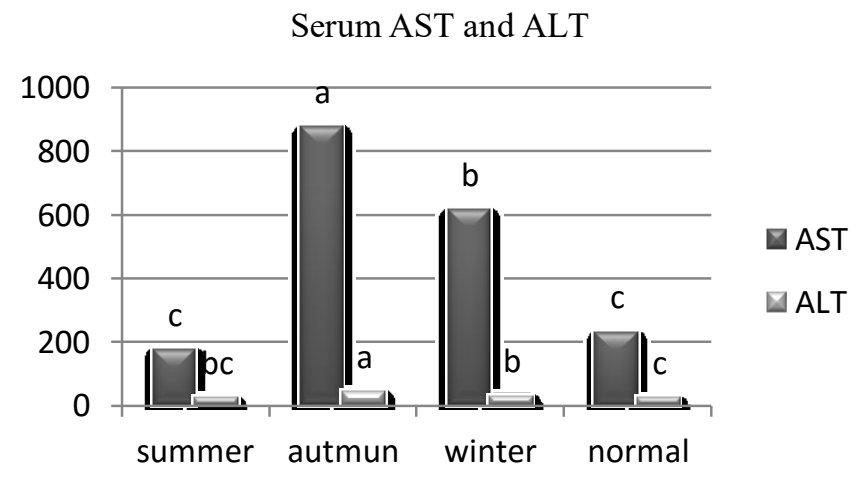

Figure 14: showing the mean concentration of the AST and ALT of serum of $O$. niloticus.
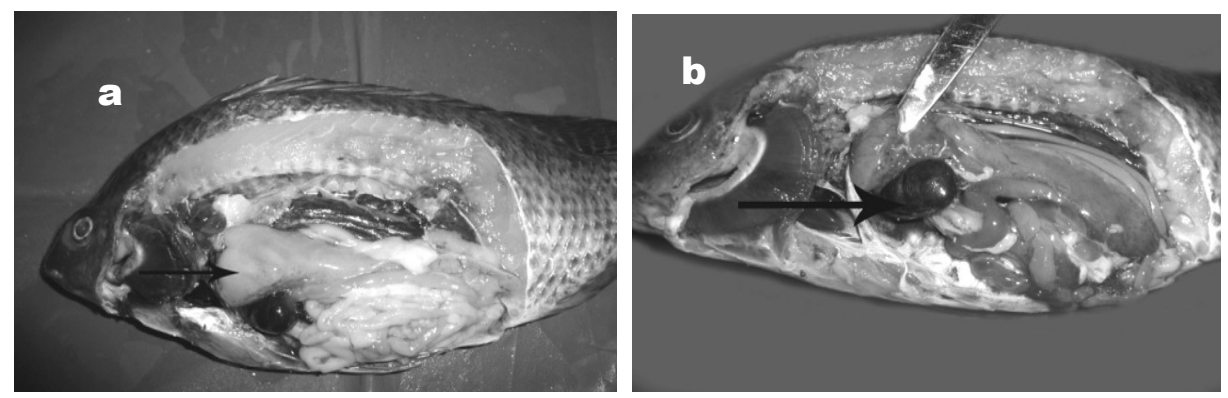

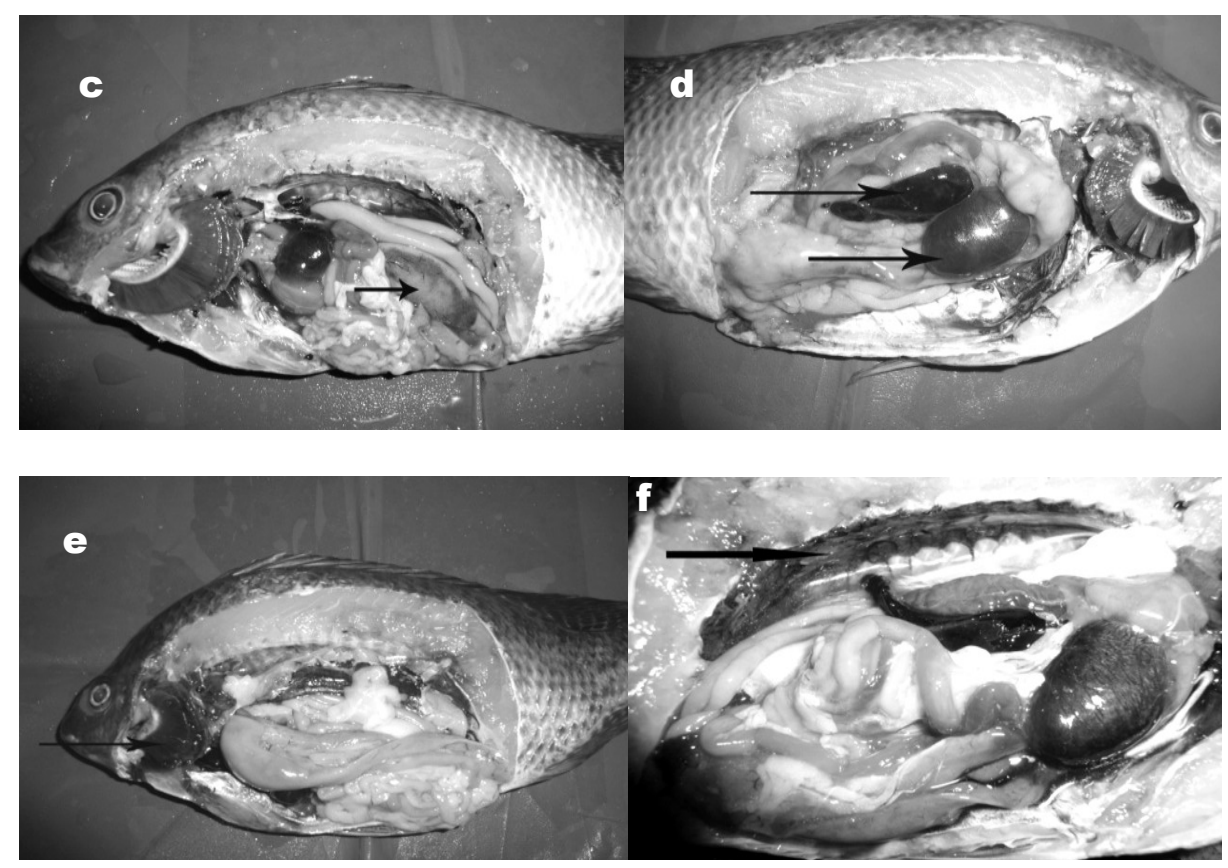

Plate 1: showing

a: $O$. niloticus showing enlarged pale liver naturally exposed to high level of copper.

b: O.niloticus showing enlarged full distended gall bladder naturally exposed to high level of cadmium.

c: O. niloticus showing congested inflammatory atches in liver naturally exposed to high level of lead.

d: O.niloticus has enlarged full distended gall bladder and enlarged congested spleen naturally exposed to high level of copper.

e: O.niloticus showing congestion of the gills naturally exposed to high level of iron and copper.

f: Oreochromis niloticus showing congestion of the kidney naturally exposed to cadmium.

\section{Discussion}

Fishes are the inhabitants that In the present work, regarding post cannot escape from the detrimental effects of pollutants (Olaifa et al, 2004) and are therefore very susceptible to physical and chemical changes which may be reflected in their blood components (Wilson and Taylor, 1993). mortem lesions in cases suffering from heavy metal exposure, liver was in some cases pale and enlarged, while in other cases showing variable degrees of congestion and hemorrhagic spots. Spleen was dark in color and 
enlarged. Kidneys appeared congested. The gall bladder was full and distended.

Comparing the average concentrations of heavy metals $(\mathrm{Zn}, \mathrm{Cu}, \mathrm{Pb}, \mathrm{Cd}$ and $\mathrm{Fe}$ ) in water of lake Temsah in different seasons, the results revealed the presence of metals in the following order : Fe $>\mathrm{Cu}>\mathrm{Pb}>\mathrm{Zn}>\mathrm{Cd}$. This result was in agreement with the finding of Abdel -Sabour et al (1998) in Lake Temsah. The water samples collected during the present study, the mean concentrations of heavy metals were higher in the summer than in the winter that agree with the finding of El-Serehy et al (2012) in water surface in west of Port Said City where Deltaic Coast of the Mediterranean Sea.

In this study, the periodic difference of heavy metals concentration based on the data of samples gathered from the fish collected from Lake Temsah that exposed the following results: summer $>$ autumn $>$ winter and that result were in agreement with Afshan et al (2014). There was no significant different between mean concentrations of the heavy metals in the water of the lake in different seasons. This mean of concentration within the permissible limits guideline values for water quality from the World Health Organization (WHO, 1996) for zinc is $(5 \mathrm{ppm})$, copper $(2 \mathrm{ppm})$, lead (0.01ppm), cadmium (0.005ppm) and iron $(0.2 \mathrm{ppm})$.

The mean concentration of heavy metals in the liver and gills of $O$. niloticus were markedly higher than those present in the edible parts of the fish and also the mean concentrations of heavy metals found in the lake water much lower than those obtained from different parts of the fish. This result agrees with finding of Mohammad (2008). The high accumulation potential of the liver is a result of the activity of metallothioneins, metal-binding proteins, which play an important role in metal regulation and detoxification of nonessential metals (Roesijadi, 1992). The pattern of metal distribution in the tissues has been suggested to reflect the route of metal uptake in fish, and this process is also strongly influenced by the water chemistry (Mager et al, 2010)

In the present study, the mean concentration of $\mathrm{Zn}$ was higher in liver followed by gills then musculature of $O$. niloticus. There was significant difference between the mean concentration of $\mathrm{Zn}$ in fish tissue in different seasons, where the highest value found in summer followed by autumn then winter .The value of $\mathrm{Zn}$ in edible part within the permissible limits set by $\boldsymbol{W H O}$ (1989) which was 40 ppm. Other workers also reported the highest concentration of $\mathrm{Zn}$ in liver of $C$. punctatus and in the gills of Labeo dyocheilus, Wallago attu by Murugan et al (2008). However, highest accumulation was seen in other organs such as gills of Tilapia zilli and O. niloticus as Akan et al $(2012$ a). Zinc is capable of 
interacting with other elements and producing antagonistic, additive or synergistic effects (Baumann and May, 1984).

In the present study, the mean concentration of $\mathrm{Cu}$ was seen high in liver followed by gills then musculature of $\mathrm{O}$. niloticus. The highest value found in O. niloticus tissue is autumn followed by summer then winter. The value of $\mathrm{Cu}$ in edible part was more than the permissible limits $(3 \mu \mathrm{g} / \mathrm{g}$.) (Wet wt.) According to $\boldsymbol{F A O} / \boldsymbol{W H O}$ (1999) value within set Permissible limits $(20 \mu \mathrm{g} / \mathrm{g})$. Copper revealed its maximum accumulation in the liver of O. niloticus study, while flesh shows the least level; this is in agreements with the findings in Tilapia zillii as Zyadah (1998) and in C. punctatus as Javed and Usmani (2013). The salinity decreases copper accumulation in fish tissues and inversely proportional to lead accumulation (Baldisserotto, 2004). Copper can combine with other contaminants such as ammonia, mercury and zinc to produce an additive toxic effect on fish (Rompala et al, 1984).

Concerning the mean concentration of $\mathrm{Pb}$, it was high in gills followed by liver then musculature of $O$. niloticus. The highest value found in summer and autumn followed by winter .The value of $\mathrm{Pb}$ in edible part was more than the permissible limits set as $(0.14 \mu \mathrm{g} / \mathrm{g}$.) according to FAO/WHO (1999) so there is a hazard from pollution with lead. It accumulates significantly in gills, livers and flesh tissue of all the fish species. The concentrations of lead were higher in the following order gills $>$ liver $>$ flesh. Similar findings were reported by Mohammad (2008) in O. niloticus, L. niloticus, also Akan et al (2012b) in Heterotis niloticus, Lates niloticus and Citharinus citharium . Lead is highly toxic to aquatic organisms, especially fish (Rompala et al, 1984). The biological effects of sublethal concentrations of lead include delayed embryonic development, suppressed reproduction and inhalation of growth, increased mucous formation, neurological problems, enzyme inhalation and kidney dysfunction (Rompala et al, 1984). In the present study, the mean concentration of $\mathrm{Cd}$ was seen in gills followed by liver then musculature. The highest value found in $O$. niloticus autumn followed by summer then winter .The value of $\mathrm{Cd}$ in edible part lower than the permissible limits set as $(0.10 \mu \mathrm{g} / \mathrm{g})$ wet weight according to $F A O / W H O$ (1999). The highest concentration of $\mathrm{Cd}$ in the gills and agree with Akan et al (2012b) finding in $O$. niloticus, $L$. niloticus .The highest concentration of $\mathrm{Cd}$ in gills because the main routes of cadmium uptake in fish are through the gills, gastrointestinal tract and olfactory rosette, also cadmium accumulates in fish olfactory system following water borne exposures (Scott et al, 2003). 
Iron was the most abundant metal in the studied tissues of $O$. niloticus. The highest $\mathrm{Fe}$ concentrations were found in summer and autumn while in the winter was in the gills. The present data showed that iron concentrations in the studied tissues were lower than US maximum permissible level for $\mathrm{Fe}(5 \mu \mathrm{g} / \mathrm{g})$ cited by Adeyeye (1993). In the fish analyzed, Fe accumulation was the maximum in all the organs but its highest value was observed in both gills and liver of. Studies reported in C. gariepinus (Osman et al, 2010) also revealed the maximum accumulation of $\mathrm{Fe}$ in liver. However, in other studies the highest accumulation was observed in the gills of $\mathrm{O}$. niloticus, $L$. niloticus (Mohammad, 2008). Accumulation levels reported in the present study for gills and liver of corroborates to the findings in $O$. niloticus and $L$. niloticus (Mohammad, 2008). Earlier reports showed Fe to be normally high in gills (Philips, 1976) or in the liver (Charbonneau and Nash, 1993).

Heavy metal exposure is known to induce changes in blood parameters of the fish (Heath, 1995). The significant decrease in $\mathrm{RBCs}, \mathrm{Hb}$ and PCV values of collected fish from the lake when compared with the normal value according to Silveira-Coffigny et al (2014) may be due to reduction in red blood cells production in the haematopoietic organs under the action of high heavy metal concentrations recorded in water samples . These results are supported by El-Boshy et al (2014) in Nile catfish, by Zaghloul et al (2007) in Oreochromis niloticus, by Praveena et al (2013) in Labeo Rohita. Such a reduction may be also be due to the intrahepatic and intrasplenic haemorrage induced by the action of accumulated heavy metals reported by Zaghloul et al (2007). Prolonged reduction in haemoglobin content is deleterious to oxygen transport and any blood dyscrasia and degeneration of the erythrocytes could be ascribed as pathological conditions in fishes exposed to toxicants reported by Shalaby (2001). The alterations in these hematological indices may be due to a defense reaction against toxicity through the stimulation of erythropoises suggested by Praveena et al (2013).

The anemic conditions in fish may be detected using haematocrit (Adakole, 2012). The PCV values always decrease when a fish loses appetite or become diseased or stressed. At present, the distinct decrease in the level of Haemoglobin and PCV after exposure to heavy metal iron clearly suggests a haemodilution mechanism possibly due to gill damage or impaired osmoregulation. The haemodilution has been interpreted as a mechanism that reduces the concentration of the irritating factor in the circulatory system. Our results are in line with Smit et al. (1979) who reported that heavy 
metal exposure results in the decrease in $\mathrm{RBC}$ count, $\mathrm{Hb}$ and PCV values are due to the impaired intestinal absorption of iron.

The WBCs counts of O.niloticus declared that, there was significant increase in different season from the lake summer $<$ autumn $<$ winter than in the normal value. In the present study, the increase in WBC has been attributed to several factors like increase in lymphocytes or squeezing of WBC's in peripheral blood. Increase in WBC count could be correlated with an increase in antibody production which helps in survival and recovery of fishes exposed to toxicant. High WBC counts indicate damage due to infection of body tissues, severe physical stress as well as Leukemia. This finding is in agreement with the finding of Nussey et al. (1995 a, b) in O. mossambicus after acute exposure to copper and Zaghloul et al. (2007) in O. niloticus .The increase in WBCs of fish was suggested to indicate alteration in defense mechanism against the action of the highly toxic and the bioaccumulated heavy metals in fish tissues as previously reported by Mazon et al(2002) and Zaghloul et al (2005).

In the present study, a significant increase of the lymphocyte, monocyte than the normal value .The differential leukocyte count highlighted the higher synthesis of Lymphocytes and Monocytes in the unstressed and stress fishes. Reduction in the erythrocyte count associated with larger production of leucocytes might have triggered the immune system totally in the fishes due to the stress of chemicals. Our result agrees with Nagarajan et al, (2014) in O. mossambicus.

Significantly the mean corpuscular volume (MCV) significant increase in summer then significantly decreased in autumn and winter seasons. Moreover, mean corpuscular hemoglobin $(\mathrm{MCH})$ significantly increased in the summer and significantly decreased in the winter while there was no significant difference from the normal value. Mean corpuscular hemoglobin concentration (MCHC) showed significant increase in the seasons more than normal value. Summer season has the highest concentration level of heavy metals in water and fish tissue associated with lowest RBCs count, $\mathrm{Hb}$ and PCV causing anemia also has leukocytosis where correlated with an increase in antibody production that indicate damage due to infection of body tissues, severe physical stress as well as Leukemia. The changes in red blood cell parameters suggested a compensatory response to the disruption of structural integrity of gills with consequent reduction of respiratory surface (tissue damage and cell proliferation), in order to increase $\mathrm{O}_{2}$ carrying capacity and maintain the level of oxygen transference from water to tissues 
(Zaghloul et al, 2005). The decrease in blood $\mathrm{Hb}$ content is accompanied by an increase in mean corpuscular volume (MCV) and mean corpuscular haemoglobin $(\mathrm{MCH})$. This may be due to the haemolytic action that led to fluid loss to the tissues with subsequent decrease in plasma volume (Swift, 1981). The MCV gives an indication of the status of size of Red blood cell and reflects an abnormal or normal cell division during erythropoises. The increase in MCV may be attributed to the swelling of erythrocytes as a result of Hypoxic condition or Osmotic stress or Macrocytic anaemia in fishes exposed to metal pollution Sinha et al (2000).

The present study showed significant differences in the studied serum constituents through the highest values in serum AST and ALT of $O$. niloticus were within the normal range. Serum total proteins play an important role in the metabolism and regulation of water balance. Blood protein and enzyme levels, in rainbow trout, are affected by metals (Dethloff et al, 1999). The serum total protein concentrations in fish collected from the lake showed significant decrease, where the total protein serum to lower levels in summer, autumn and winter than normal value $(3.9 \mathrm{~g} / \mathrm{dl})$ reported by Hrubec et al (2000). The recorded hypoproteinamiais may be explained on the basis of energy production during pollutant toxicity and/or due to other several pathological processes including renal damage and elimination in hepatic blood flow and/or plasma dissolution as reported by Gluth and Hanke (1985). Hypoproteinemia in this study was in agreement with the findings of Mekkawy et al (2011) who recorded that $O$. niloticus exposed to $\mathrm{Cd}$ for 15 and 30 days showed a reduction in serum protein levels This decrease of total protein may be due to the destruction of protein synthesizing subcellular structures and inhibition of the hepatic synthesis of blood protein (Fontana et al, 1998). Loss of protein from damaged kidneys could contribute further to the observed hypoproteinemia.

The elevation in serum AST and ALT activities of $O$. niloticus may be attributed to the damage of liver cells by the action of the accumulated heavy metals. The same results were previously reported in case of different fish species exposed to different heavy metals (Elghobashy et al, 2001 and Gad, 2005). The following cell damage, the membranes become permeable and the enzymes are found in the extracellular fluid and serum. So, determination of transaminases, (AST, ALT) has proven useful in the diagnosis of liver disease in fish (Sandnes et al, 1988). Also, Cell injury of certain organs leads to the release of tissuespecific enzymes into the blood stream (Chen et al. 2004). The 
significant increase of transaminases (AST and ALT) activity in fish exposed to heavy metals may reveal possible leakage of enzymes across damaged plasma membranes and/or the increased synthesis of enzymes by the liver.

\section{REFERENCES}

Abdel Fattah, N.A., (1992): Detection of Pesticide Residues in Market .Fish. M.V. Sci. University, Cairo.

Abdel -Sabour M. F. A.; Khali, M.T. and Attwa, A. H. A. (1998): Indictors of Lake Temsah Potential Pollution by Some Heavy Metals. International Conference on Hazardous Waste Sources, Effects and Management 12-16 December 1998. Cairo-Esvpt p: 207-215.

Abou EL-Naga, E. H.; ELMoselhy, K. M. and Hamed, M. A. (2005): Toxicity of cadmium and copper and their effect on some biochemical parameters of marine fish Mugil seheli. Egyptian. J. Aquat. Res., 31 (2), 60-71.

Adakole, J.A. (2012): Changes in some haematological parameters of the African catfish (Clarias gariepinus) exposed to a metal finishing company effluent, Indian Journal of Science and Technology, 5,4 .

Adeyeye, E., (1993): Trace heavy metals distribution in Illisha africana fish organs and tissue. II: Chromium, zinc, copper, iron and cobalt. Pakistan Journal of Science Research, 36: 333-337.
Afshan, S.; Shafaqat Ali; Uzma Shaista Ameen; Mujahid Farid; Saima Aslam Bharwana; Fakhir Hannan and Rehan Ahmad ,(2014): Effect of Different Heavy Metal Pollution on Fish. Research Journal of Chemical and Environmental Sciences Volume 2 Issue 1: 74-79. Available Online http://www.aelsindia.com.

Akan C. J. ; Salwa Mohmoud; Bashir Shettima Yikala and Victor

Ogugbuaja,(2012a):

Bioaccumulation of Some Heavy Metals in Fish Samples from River Benue in Vinikilang, Adamawa State, Nigeria American Journal of Analytical Chemistry,VOL.3, 727736

http://dx.doi.org/10.4236/ajac.2012. 311097

Akan C.J.; Salwa, M.; Yikala, B. S. and Chellube , Z. M. (2012 b): Study on the Distribution of Heavy Metals in Different Tissues of Fishes from River Benue Vinikilang, Adamawa State, Nigeria. British Journal of Applied Science \& Technology2(4): 311 333, 2012 SCIENCEDOMAIN international www.sciencedomain.org

APHA,(2005): Standard Method for the Examination of Water and Wastewater,2 ${ }^{\text {st }}$ ed. American Public Health Association, Washington, D.C.

Baldisserotto, B.; Kamunde, C.; A. Matsuo and Wood, C.M. (2004): A protective effect of dietary calcium against acute 
waterborne cadmium uptake in rainbow trout. Aquatic Toxicology, 67: 57-73.

Basa, Siraj, P. and Usha Rani A., (2003): Cadmium induced antioxidant defense mechanism in freshwater teleost Oreochromis mossambicus (Tilapia). Eco. Toxicol. Environ. Saf., 56 (2), 218 221.

Baumann, P.C. and May, T.W (1984): Nickel residues in fish from inland waters of the United States. In Workshop proceedings, the effects of trace elements on aquatic ecosystems. Electric Power Research Institute, Palo Alto, CA, 7, 1-16.

Charbonneau, C.S. and Nash, T. (1993): Contaminants program, Mingo National Wildlife Refuge (Region 3), contaminants survey results. U.S. Fish and Wildlife Service, 608 East Cherry Street, Room 200, Columbia, Missouri 65201.

Chen, C.; Wooster, G.A. and Bowser, P.R., (2004): Comparative blood chemistry and histopathology of tilapia infected with Vibrio vulnificus or Streptococcus iniae or exposed to carbon tetrachloride, gentamicin or copper sulfate. Aquaculture 239, 421-443.

Conroy D.A. and Herman L.R. (1981): Textbook of fish diseases.T.F.H. Publ,West Sylvania. Dethloff, G.M.; Schlenk, D.; Khan, S. and Bailey, H.C. (1999): The effects of copper on blood and biochemical parameters of rainbow trout (Oncorhynchus mykiss ). Arch.
Environ. Contam. Toxicol., (36):415-423.

Duncan, R.M., (1955): Multiple range and multiple $f-$ tests. Biometrics, 11: 1-42.

El-Boshy, M.; Hossam Ali Gadalla and Fatma Mostafa Abd El-Hamied (2014): Immunological, hematological and biochemical changes induced by short term exposure to cadmium in catfish (Clarias gariepinus). Journal of Coastal Life Medicine ; 2(3): 175180.

Elghobashy, A.H.; Zaghloul, K.H. and Metwally. M.A. (2001): Effect of some water pollutants on the Nile tilapia; Oreochromis niloticus collected from the river Nile and some Egyptian Lakes.Egypt.J.Aquat. Biol. Fish., 5(4): 251- 279.

El-Serehy, A.; Hamdy Aboulela; Fahad Al-Misned; Mona Kaiser; Khaled Al-Rasheid and Heba Ezz El-Din , (2012): Heavy metals contamination of a Mediterranean Coastal Ecosystem, Eastern Nile Delta, Egypt. Turkish Journal of Fisheries and Aquatic Sciences 12: 751-760 (2012) ISSN 1303-2712 DOI: $\quad 10.4194 / 1303-2712-$ v12_4_03. www.trjfas.org.

FAO/WHO, (1999): Expert Committee on Food Additives.Summary and conclusion, 53rd meeting, Rome, 1-10 June.

Farombi, E. O.; Adelowo, O. A. and Ajimoko. Y. R., (2007): Biomarkers of oxidative stress and heavy metal levels as indicators of environmental pollution in African 
Cat fish (Clarias gariepinus) from Nigeria ogun river. Int. J. Environ. Res. Public Health., 4 (2), 158-165.

Fontana, L.; Moreira, E.; Torres, M.; Ferna'ndez, I.; Rios, A.; Sanchezde Medina, F. and Gil, A., (1998): Dietary nucleotides correct plasma and liver microsomal fatty acids alterations in rats with liver cirrhosis induced by oral intake of thioacetamide. J. Hepatol. 28, 662669.

Gad, N.S., (2005): Impact of environmental pollution in the southern region of Lake Manzalah Egypt on some biochemical parameters of Tilapia Zilii. J. Egypt. German Soc. Zool. 48A, 279-298.

Gluth, G. and Hanke, W. (1985): A comparison of physiological changes in crap, Cyprinus carpio induced by several pollutants of sublethal concentrations. I- The dependency on exposure time. Ecotoxicol. Environ. Safety, 9: 179188.

Heath, A.G. (1995): Water Pollution and Fish Physiology. CRC. Press. Inc. Boca Raton, Florida. 359pp.

Hrubec, T. C.; Cardinante, J. L.; and Smith, S. A. (2000): Hematology and serum chemistry reference intervals for cultured tilapia (Oreochromis hybrid). Vet. Clin. Pathol. 29: 7-12.

Javed M. and Usmani N., (2013): Assessment of heavy metals $(\mathrm{Cu}$, $\mathrm{Ni}, \mathrm{Fe}, \mathrm{Co}, \mathrm{Mn}, \mathrm{Cr}, \mathrm{Zn}$ ) in rivulet water, their accumulations and alterations in hematology of fish Channa punctatus. African Journal of Biotechnology Vol.13(3),pp.492501.http://www.academicjournals.o $\mathrm{rg} / A J B$

King, E.J. and Wootton, I.D.P.(1959): Determination of total protein. Micro_analysis in Medical Biochemistry, Churchill, London.

Mager, E. M.; Brix, K. V. and Grosell, M. (2010): Influence of bicarbonate and humic acid on effects of chronic waterborne lead exposure to fathead minnow (Pimephales promelas). Aquatic Toxicology, 96, 135-144.

Massanyi ， P.; Trandzik, J.;Nad, P. ;Toman, R. ;Skalick, M. and Kornekov, B. (2003): Seminal concentration of trace elements in various animals and their correlations. Asian Journal of Andrology 5:101-104.

Mazon, A. F.; Monteiro, E. A. S.; Pinheiro, G. H. D. and Fernandes, M. N. (2002): Gill cellular changes induced by copper exposure in the South American tropical freshwater fish Prochilodus scrofa. Environm. Res. A., 88: 52-63.

Mekkawy, A.A.; Mahmoud, U.M.; Wassif, E.T. and Naguib, M., (2011): Effects of cadmium on some haematological and biochemical characteristics of Oreochromis niloticus (Linnaeus, 1758) dietary supplemented with tomato paste and vitamin E. Fish Physiol. Biochem. 37, 71-84.

Mohammad, F.A. (2008):Bioaccumulation of selected metals and histopathological alterations in tissues of 
Oreochromis niloticus and Lates niloticus from lake Nasser, Egypt. Global Veterinaria, 4(2), 205- 218.

Mona S. Zaki, A. Y. Gaafar and Nagwa S. Ata (2015): Minimize of Cadmium by Medicinal Plants ,Life Science Journal 2015;12(2).

Murugan S. S.; Karuppasamy, R.; Poongodi, R. and Puvaneswari, S. (2008): Bioaccumulation patterns of zinc in fresh water fish Channa punctatus (Bloch.) after chro- nic exposure. Turkish journal of Fisheries and Aquatic Sciences 8, pp 55- 59.

Nagarajan K., Kannan S. and Gunasekaran G,(2014): Study of growth and Haematology of the Fish Oreochromis mossambiccus Grown in the Kullursandhai Reservoir water of Virudhunagar District,India under the Cadmium Chloride Stress. International Research Journal of Environment Sciences Vol. 3(3), 49-54 ISSN 2319-1414.

Nussy, G.; Van Vuren, J. H. J. and Du preez, H.H. (1995a): Effect of copper on haematology and osmoregulation of the Mozmbique tilapia; Oreochromis mossambicus (Cichlidae). Comp.Biochem. Physiol., 111(c): 369- 380.

Nussy, G.; Van Vuren, J. H. J. and Du preez, H.H. (1995b): Effect of copper on differential white blood cell counts of the Mozmbique tilapia Oreochromis mossambicus (Cichlidae). Comp.Biochem. Physiol 111(c): 381- 388.
Olaifa, F.E.; Olaifa, A.K.; Adelaja, A.A.; Owolabi, A.G. (2004): Heavy metal contamination of Clarias gariepinus from a Lake and Fish farm in Ibadan, Nigeria. Afr. J. Biomed. Res. 7:145 -148.

Osman, A.; Alaa, G.M. and Werner, K. (2010): Water Quality and Heavy Met.al Monitoring in Water, Sediments and Tissues of the African Catfish Clarias gariepinus (Burchell, 1822) from the River Nile, Egypt. Journal of Environmental Protection, 1, 389400.

Philips, D.J.H., (1976): The common mussel Mytillus edulis as an indicator of pollution by $\mathrm{Zn}, \mathrm{Cd}$, $\mathrm{Pb}$ and $\mathrm{Cu}$. 1. Effect of environmental variables on uptake of metals. Mar. Biol., 38, 59-66.

Praveena, M.; Sandeep, V.; Kavitha, N. and Jayantha Rao, K. (2013): Impact of Tannery Effluent, Chromium on Hematological Parameters in a Fresh Water Fish, Labeo Rohita (Hamilton). Research Journal of Animal, Veterinary and Fishery Sciences Vol. 1(6), ISSN $2320-6535$.

Reitmans, S. and Frankel, S.(1957): A colorimetric method for the determination of serum glutamic oxaloacetic and glutamic pyruvic transaminases. Am.J.clin.Pathol., 28: 53-56.

Roesijadi,

G.

(1992):

Metallothioneins in metal regulation and toxicity in aquatic animals. Aquatic Toxicology, 22, 81-113. Cited by Dsikowitzky et al., (2012). 
Rompala, J.M.; Rutosky, F.W.; Putnam, D.J.

(1984):

Concentrations of environmental contaminants from selected waters in Pennsylvania. U.S. Fish Wildl. Serv. Rep., State College, Pennsylvania., 102.

Sandnes , K.; Lie, Q. and Waagbq, R. (1988): Normal ranges of some blood chemistry parameters in adult farmed Atlantic salmon; Salmo salar. J. Fish Biol., 32: 129 136.

Scott, G.R.; Sloman, K.A.; Rouleau, C. and Wood, C.M. (2003): Cadmium disrupts behavioral and physiological response to alarum substance in juvenile rainbow trout, oncorhynchus mykiss. Journal of Experimental biologyical206:17791790.

Senthilkumar, K.: Kannan,K.; Subramanian, A. and Tanabe, $S$. (2001): Accumulation of organochlorine pesticides and polychlorinated biphenyls in sediments, aquatic organisms, birds, bird eggs and bat collected from South India. Environ. Sci. Pollut. Res. Int., 8(1): 35-47.

Shah, S.L. and Altindag, A. (2004a): Haematological parameters of tench (Tinca tinca $\mathrm{L}$ ) after acute and chronic exposure to lethal and sublethal mercury treatments. Bull. Environ. Contam. Toxicol. 73:911-918.

Shalaby A.M., (2001): Protective effect of Ascorbic acid against Mercury intoxication in Nile tilapia (Oreochromis niloticus), J. Egypt.
Acad. Soc. Environ. Develop. (DEnvironmental studies), 2(3), 79 $-97$.

Silveira-Coffigny; Prieto-Trujillo, R. A. and Ascencio-Valle, F. (2014): Effects of different stressors in haematological variables in cultured Oreochromis aureus S. Comparative Biochemistry and Physiology, Part C 139 (2004) 245250.

Sinha, A. K.; Sinha M. K. and Adhikari, S., (2000): Effect of the copper toxicity on haematological profile of Indian major corp, Lobeo rohita, Hand book Industry Environment and Pollution, 166172 .

Smit, G.L.; Hatting, J. and Burger, A.P., (1979):Haematological assessment of the effects of the anaesthetic MS222 in natural and neutralized form in three fresh water fish species: Interspecies differences, Journal of Fish Biology, 15, 633643.

Swift, D.J. (1981): A holding box system for physiological experiment on rainbow trout (Salmo gairdneri Rich.) requiring rapid blood sampling. Fish. Biol., 18: 309-319.

WHO, (1989): Heavy metalsenvironmental aspects. Environment Health Criteria No. 85, World Health Organization, Geneva, Switzerland.

WHO, (1996): Guidelines for Drinking-Water Quality. World Health Organisation, Geneva, Switzerland. 
Wilson, R.W. and Taylor, E.W. (1993): The physiological responses of freshwater rainbow trout, Onchorynchus mykiss, during acute exposure. J. Comp. Physiol. 163b:38-47.

Zaghloul, H.: Wafaa, S Hasheesh; Iman, A. Zahran and Mohamed-Assem S. Marie, (2007): Ecological and biological studies on the Nile tilapia Oreochromis niloticus along different sites of Lake Burullus.
Egypt. J. Aquat. Biol. \& Fish., Vol. 11, No.3: $57-88$.

Zaghloul, K.H.; Omar, W.A. and Abo-Hegab, S. (2005): Environmental hazard risk assessment on; Oreochromis niloticus and Tilapia zilli fsh. J. Egypt. Ger. Sco. Zool., 46(A): 105139.

Zyadah, A.M., (1998): Accumulation of Some Heavy Metals in Tilapia zillii Organs from Lake Manzalah, Egypt. Tr. J. of Zoology 23 : 365-372.

\section{الملخص العربي}

دراسة عن التلوث ببعض المعادن الثقيلة في مياه واسماك البلطي في بحيرة التمساح إسماعيل عبد المنعم عيسي ، حسن دروة ، مني محمد عبد الوهاب ، محم وفيق، شيماء فخري

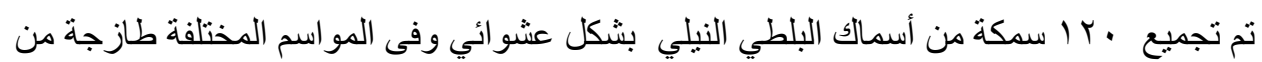

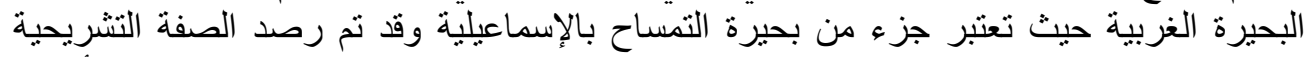

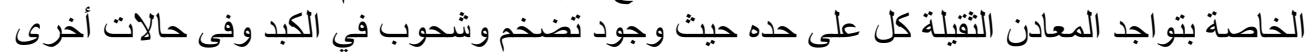

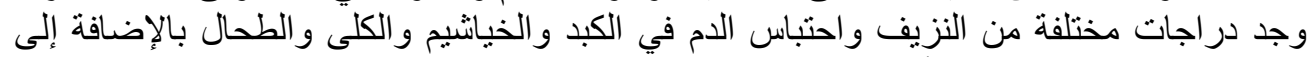

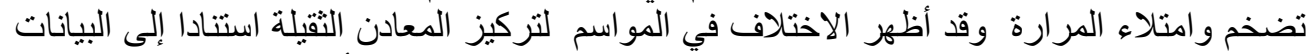

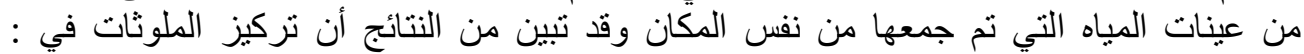

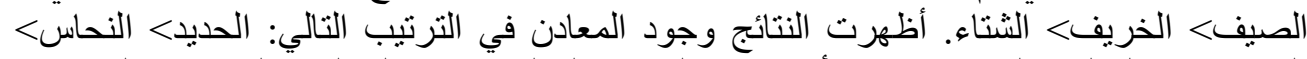

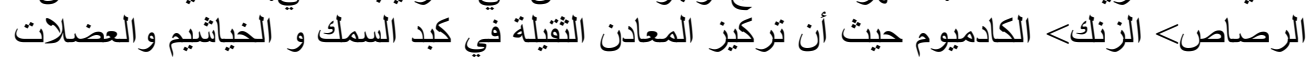

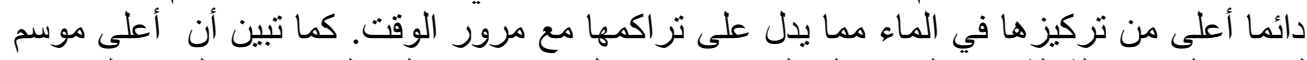

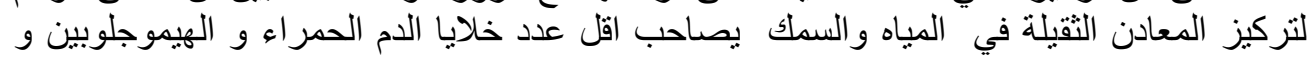

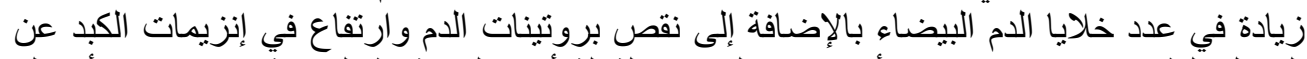

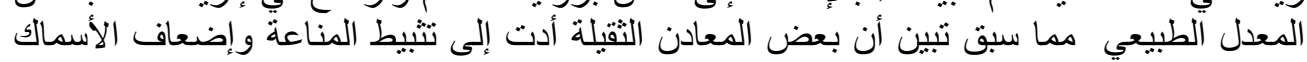

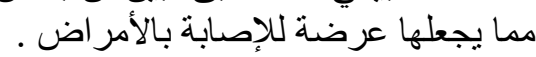

